Review Article

\title{
A Review on Green Synthesis, Biomedical Applications, and Toxicity Studies of ZnO NPs
}

\author{
V. N. Kalpana and V. Devi Rajeswari 10 \\ Department of Biomedical Sciences, School of Biosciences and Technology, VIT, Vellore, Tamil Nadu, India \\ Correspondence should be addressed to V. Devi Rajeswari; vdevirajeswari@vit.ac.in
}

Received 9 February 2018; Revised 26 June 2018; Accepted 4 July 2018; Published 1 August 2018

Academic Editor: Francesco Paolo Fanizzi

Copyright (c) 2018 V. N. Kalpana and V. Devi Rajeswari. This is an open access article distributed under the Creative Commons Attribution License, which permits unrestricted use, distribution, and reproduction in any medium, provided the original work is properly cited.

\begin{abstract}
The advance of reliable and eco-friendly strategies for the development of nanoparticles is a fundamental key to the discipline of nanotechnology. Nanoparticles have been continuously evaluated and have been used in many industrial applications for a decade. In particular, the role of zinc oxide nanoparticles ( $\mathrm{ZnO} N P s$ ) has received a great interest because of various properties such as UV filter properties and photochemical, antifungal, high catalyst, and antimicrobial activities. Because of the high rate of poisonous chemicals and the extreme surroundings used within the chemical and physical methods, the green techniques have been adopted using plants, fungi, bacteria, and algae for the synthesis of nanoparticles. Therefore, this paper considers various green synthesis methods to provide the evidence of $\mathrm{ZnO} \mathrm{NP}$ role to several applications, and in addition, biomedical applications and toxic effect were reviewed. Therefore, the paper used various secondary sources to collect the relevant review articles. From the findings, the green route of synthesis is rather safe and eco-friendly when compared to physical and chemical means of synthesis. On the other hand, its biomedical applications in this sector are increased day by day in various processes including bioimaging, drug delivery, biosensors, and gene delivery. With respect to its toxicity properties, ZnO NPs can act as smart weapons against multiple drug-resistant microorganisms and as a talented substitute for antibiotics.
\end{abstract}

\section{Introduction}

In science and technology, one among the rapidly developing concepts in the latest years is nanotechnology, which has brought tremendous development. The nanomaterial which comprises distinctive physicochemical properties has the potential to develop new systems, structures, devices, and nanoplatforms with impending bids in extensive variety of disciplines [1,2]. Nanomaterials are particles that are in nanoscale size, and they are very small particles with improved thermal conductivity, catalytic reactivity, nonlinear optical performance, and chemical stability due to their large surface area-to-volume ratio [3]. This quality has attracted many researchers to locate novel techniques for their synthesis. Though conventional techniques (physical and chemical methods) use less time to synthesize bulk amount of nanoparticles, they require toxic chemicals like protective agents to maintain stability, which leads to toxicity in the environment. Keeping this in mind, green technology by using plants is rising as an eco-friendly, nontoxic, and safe option, since plant extract-mediated biosynthesis of nanoparticles is economically advantageous and offers natural capping agents in the form of proteins [4]. To regulate chemical toxicity in the environment, biological synthesis of various metal oxide and metal nanoparticles through plant extraction is used, which is a marginal technique for regulating chemical synthesis, and it permits a distinct shape and size of nanoparticles with a meticulous synthesis [5].

For biomedical applications, improvement in biodegradable, functionalized, and biocompatible nanomaterials is being remained a tremendous vivacious area for research. Until now, among numerous other biomedical applications [6-9] well examined are paramagnetic nanoparticles [10,11], quantum dots (QDs) $[6,12]$, nanoshells [13], and carbon nanotubes (CNTs) [14, 15]. An extensive variety of nanostructures could exhibit zinc oxide $(\mathrm{ZnO})$, 
which has exclusive properties such as semiconducting, piezoelectric, and optical [16, 17]. Hence, nanomaterials based on $\mathrm{ZnO}$ are deliberated for extensive range of applications such as energy storage, nanosensors, cosmetic products, nano-optical devices, nanoelectronic devices, and so on [18-23]. Biodegradability and low toxicity are one among the most significant characteristics of $\mathrm{ZnO}$ nanomaterials. For adults, an indispensable trace element is $\mathrm{Zn}^{2+}$ and it is being elaborated into numerous features of metabolism. In acidic and strong basic conditions, $\mathrm{ZnO}$ NPs could be dissolved slowly. Solubilized $\mathrm{ZnO}$ nanoparticles have shown that the release of $\mathrm{Zn}^{2+}$ ions can exert stress on cells and have adverse impacts on different organisms [24]. The required properties of $\mathrm{ZnO}$ nanomaterials have attained increased concern towards biomedical applications [25]. The $\mathrm{ZnO}$ nanoparticle's toxic effect is due to their solubility. In the extracellular areas, $\mathrm{ZnO}$ nanoparticles are dissolved, which sequentially raise the level of intracellular $\left[\mathrm{Zn}^{2+}\right]$. The dissolution of $\mathrm{ZnO}$ nanoparticles in the medium and the mechanism of increased intracellular $\left[\mathrm{Zn}^{2+}\right]$ level are still speculative [26].

Holistically, this review will summarize the current status of the use of $\mathrm{ZnO}$ nanomaterials for biomedical applications, their green synthesis nature, and its toxic effect.

Organic nanoparticles and inorganic nanoparticles are the two categories of nanoparticles based on their components. Organic nanoparticles include carbon nanoparticles (fullerenes), whereas inorganic nanoparticles include magnetic nanoparticles, noble metal nanoparticles (gold and silver), and semiconductor nanoparticles (such as zinc oxide and titanium dioxide) [27]. Nanoparticles can also be categorized based on their origin, dimensions, and structural content.

Based on the origin of nanomaterial, it is categorized into natural nanomaterial and artificial nanomaterial [28]. On considering the dimensions of nanomaterial, it is categorized as zero-dimensional (0D), one-dimensional (1D), two-dimensional (2D), and three-dimensional (3-D) nanomaterials. The zero-dimensional nanomaterials have nanodimensions at all three directions; one-dimensional nanomaterials have only one nanodimension which is exterior to the nanometer range; and two-dimensional nanomaterials have two nanodimensions exterior to the nanometer range, whereas three-dimensional nanomaterials have all the nanodimensions exterior to the nanometer range. These comprise bulk materials developed with individual blocks that are in the nanometer scale $(1-100 \mathrm{~nm})$ [29].

According to the structural configuration and morphology, nanomaterials have been divided into amalgamated materials and nanodispersions. Extremely branched macromolecules are dendrimers with the dimensions in the nanometer scale. In the metal-based materials, the chief component for these particles is metal, where the nanomaterials comprised nanosilver, nanogold, metal oxides like titanium dioxide, and finally closely packed semiconductors such as quantum dots. The morphology of carbon-based nanomaterials is tubes, hollow spheres, or ellipsoids. The carbon nanomaterials that are spherical and ellipsoidal are referred as fullerenes and cylindrical ones are called as nanotubes [28].

\section{Nanoparticle Synthesis Methods}

Bottom-up and top-down are the two approaches recommended for the biosynthesis of nanoparticles [30]. In case of a bottom-up approach, the most important reaction occurred is oxidation/reduction. The synthesis of nanoparticles is currently an important area of research, which seeks an eco-friendly approach and green materials for current scenario [31]. The major steps involved in the preparation of nanoparticles that have to be evaluated from the point of green chemistry are (i) the solvent medium used for the synthesis, (ii) environmentally benign reducing agent, and (iii) the nontoxic material for the stabilization of the nanoparticles. The majority of the chemical and physical methods mentioned so far largely depend on organic solvents. This is principally due to the hydrophobicity of the capping agents used [32]. Synthesis with bio-organisms is compatible with the principles of green chemistry: (i) ecofriendly approach, (ii) the reducing agent used, and (iii) the capping agent in the reaction. The synthesis of inorganic metal oxide nanoparticles using biological elements has received immense attention due to their unusual properties (optical, electronic, chemical, etc.) [33].

\section{Zinc Oxide Nanoparticles}

Metal oxides play a very significant role in the science of materials, such as the production of microelectronic circuits, sensors, piezoelectric devices, fuel cells, surface passivation coatings, and corrosion catalysts. Metal oxides have also been used as absorbers of the environmental pollutant. In nanotechnology, oxide nanoparticles can show signs of unique chemical properties due to their limited size and high density of edges. An n-type semiconducting metal oxide is $\mathrm{ZnO}$. Over the past few years, more interest is drawn towards zinc oxide NP since it has wider varieties of applications particularly in the fields of biomedical systems, optics, and electronics [34-40]. Among all these types of metal oxides, $\mathrm{ZnO}$ NPs attract much attention because of their stimulating properties [41] (such as the high direct bandwidth of $3.3 \mathrm{eV}$ at room temperature and high excitation energies of $60 \mathrm{meV}$ ) [42], optical property, high catalytic activity, anti-inflammatory, wound healing, and UV filtering properties [1,43-48]. Several authors have reported $\mathrm{ZnO}$ biosensors for cholesterol, enzyme biochemistry, and other biosensing applications $[49,50]$.

Zinc oxide as a nonhygroscopic and nontoxic, inorganic, polar, crystalline material is a very cheap, safe, and readily available, which has aroused great interest in various organic transformations, sensors, transparent conductors, and surface acoustic wave devices [51-53]. The $\mathrm{ZnO} \mathrm{NP}$ is an exclusive material that has semiconducting, piezoelectric, and pyroelectric properties and has versatile applications in transparent electronics, UV light emitters, chemical sensors, spin electronics, personal care products, catalyst, coating, and paints $[54,55]$. Due to these unique properties, $\mathrm{ZnO}$ NPs find applications in antireflection coatings, transparent electrodes in solar cells, UV light emitters, diode lasers, varistors, piezoelectric devices, spin electronics, surface 
acoustic wave propagators [52], as an antibacterial agent [56], as photonic material [57], and for gas sensing [58]. The biomolecules in the plant extract act as efficient capping agents, thus playing a major role in the NP synthesis. The capping agents seem to stabilize NPs through different mechanisms that include electrostatic stabilization, steric stabilization, stabilization by hydration forces, and stabilization using van der Waals forces. The stabilization of NPs is significant for its functions and its applications [59]. The utility of ZnO NPs in the field of food preservation and packaging industry when applied to biodegradable polymeric metrics and $\mathrm{ZnO}$ NPs has improved the quality of food and packaging mainly through three mechanisms, namely, the release of antimicrobial ions, destructing the integrity of the cells of bacteria, and formation of ROS due to light radiation [60]. Elmer and White reported the pesticidal properties of the $\mathrm{ZnO}$ by spraying synthesized $\mathrm{ZnO}$ on tomato and eggplant and it was noted that $\mathrm{ZnO}$ reduced disease estimate of $28 \%$ when compared to the control [61]. In vitro approaches use plant extracts to reduce zinc salt (zinc nitrate, sulfate, chloride, and many others) and endow with control over the size and shape of the nanoparticles. Fundamentally, the primary and secondary metabolites are present in plants, for example, saponins, tannins, starches, polypeptides, terpenoids, flavonoids, and phenolics, which act as reducing and capping agents. Mild solvents such as water, ethanol, and methanol are used for the extraction of the plant metabolites, which are allowed to react with the zinc salt solution in different conditions to achieve greatest yield [62-65].

\section{Green Synthesis of ZnO NPs}

Owing to the growing popularity of green methods, several methods have been implemented to produce $\mathrm{ZnO}$ NPs using different sources such as bacteria, fungus, algae, plants, and others. A list of tables was prepared to summarize the research carried out in this field (Table 1).

4.1. Plant-Mediated Biosynthesis of $\mathrm{ZnO} N$ NP. The synthesis of biological nanoparticles represents an alternative for the physical and chemical methods of nanoparticle formation. The majority of researchers focused on the green synthesis of nanoparticles for the formation of metal and oxide nanoparticles (Figure 1). The use of plants for the synthesis of nanoparticles is a rapid, low-cost, eco-friendly option and is safe for human use [31].

Vitex negundo plant extract was used to produce $\mathrm{ZnO}$ NPs with zinc nitrate hexahydrate as a precursor. The biosynthesized $\mathrm{ZnO}$ NPs showed antimicrobial activities against E. coli and S. aureus bacteria [77]. Dobrucka and Dugaszewska [78] used Trifolium pratense to synthesize $\mathrm{ZnO}$ NPs. The synthesized ZnO NPs were found to be of hexagonal shape and the sizes were found to be of $60-70 \mathrm{~nm}$. Kalpana et al. [79] synthesized ZnO NPs using Lagenaria siceraria pulp extract. In addition, the author evaluated the biosynthesized $\mathrm{ZnO}$ nanoparticles for antidandruff, antimicrobial, and antiarthritic efficacy.
Dhanemozhi et al. [80] successfully synthesized the $\mathrm{ZnO}$ NPs from green tea leaf extract to evaluate their capacitance behavior for supercapacitor applications. ZnO NPs are known to be multifunctional inorganic nanoparticles with their major application in the treatment of urinary tract infection. Santhoshkumar et al. [81] synthesized the $\mathrm{ZnO}$ NPs using Passiflora caerulea leaf extract and tested against the pathogenic culture isolated from the urine of the patient suffering from urinary tract infection. The results showed that the synthesized $\mathrm{ZnO}$ NPs act as an antibacterial agent against urinary tract infection. Nava et al. [82] dealt with low-cost, nontoxic green synthesis of $\mathrm{ZnO}$ NPs prepared using Camellia sinensis extract. The efficiency of $\mathrm{ZnO}$ NPs as a photocatalyst for the degradation of various organic dyes such as methylene blue and methyl orange and their antioxidant activity by the DPPH assay has been studied by Siripireddy and Mandal [83] using Eucalyptus globulus. The synthesis of monophase crystalline $\mathrm{ZnO}$ nanoparticles with a size range of about $15.8 \mathrm{~nm}$ by the green novel and environmentally friendly pathway using the extract of $A$. betulina as an effective oxidizing/reducing agent has been demonstrated for the first time by Thema et al. [84]. Stable and spherical $\mathrm{ZnO}$ NPs were produced by using zinc nitrate and Aloe vera leaf extract. The various properties of $\mathrm{ZnO}$ NPs were characterized by the use of the UV-Vis spectrophotometer, FTIR, photoluminescence, XRD, SEM, and TEM analysis [43].

4.2. Microbe-Mediated Biosynthesis of ZnO NPs. Synthetic pathways of nanoparticles by microbes may involve combinations of basic cell biochemistry, the transport of ionic metals both in and out of cells, mechanism of resistance of microbes to toxic metals and activated metalbinding sites, ion accumulation metallic intracellular, and nucleation of metal oxides [85]. ZnO NPs were rapidly synthesized from a Rhodococcus pyridinivorans NT2 which were found to be moderately stable and roughly spherical with an average diameter of the particle of 100-120 nm [86]. Serratia ureilytica (HM475278)mediated $\mathrm{ZnO}$ NPs have been reported by Dhandapani et al. [87]. ZnO NPs have aroused interest because of their many applications in the food industry. Selvarajan and Mohanasrinivasan [88] described an innovative method for the biosynthesis of $\mathrm{ZnO}$ NPs using a probiotic bacterium Lactobacillus plantarum VITES07. Kundu et al. [86] synthesized $\mathrm{ZnO}$ NPs from the zinc sulfate solution using an actinobacteria Rhodococcus pyridinivorans NT2. The synthesized ZnO NPs were explored for multifunctional textile finishing and for in vitro anticancer drug delivery in HT-29 colon carcinoma cell line. The studies of Shamsuzzaman et al. [89] have described the simple and green route for the biosynthesis of $\mathrm{ZnO}$ nanoparticles using Candida albicans as a capping and reducing agent. The author also used the synthesized ZnO NPs as a catalyst for the rapid and efficient synthesis of steroidal pyrazoline. Hussein et al. [85] reported Bacillus cereus as a biotemplate agent for the formation of $\mathrm{ZnO}$ NPs with raspberry and plate-like structures through a simple 
TABLE 1: Green synthesis of ZnO NPs using various sources.

\begin{tabular}{|c|c|c|c|c|c|}
\hline $\begin{array}{l}\text { Type of green } \\
\text { method }\end{array}$ & Applied material/organism & $\begin{array}{c}\text { Particle } \\
\text { size }(n m)\end{array}$ & Morphology of NPs & Activity carried out & References \\
\hline \multirow{11}{*}{$\begin{array}{l}\text { Plant-mediated } \\
\text { synthesis }\end{array}$} & Limonia acidissima (leaf) & $12-53$ & Spherical & $\begin{array}{l}\text { Antibacterial activity against } \\
\text { Mycobacterium tuberculosis }\end{array}$ & {$[39]$} \\
\hline & Euphorbia Jatropha (stem) & 15 & Hexagonal & Used as semiconductors & {$[66]$} \\
\hline & Ceropegia candelabrum (leaf) & $12-35$ & Hexagonal & $\begin{array}{l}\text { Antibacterial potential against } \\
\text { Staphylococcus aureus, Bacillus } \\
\text { subtilis, Escherichia coli, } \\
\text { Salmonella typhi }\end{array}$ & {$[67]$} \\
\hline & Celosia argentea (leaves) & 25 & Spherical & $\begin{array}{l}\text { Antibacterial potential against } \\
\text { Escherichia coli, Salmonella, } \\
\text { Acetobacter; drug delivery } \\
\text { Bacillus cereus, Klebsiella }\end{array}$ & {$[68]$} \\
\hline & Couroupita guianensis (leaves) & 57 & Hexagonal unit cell & $\begin{array}{c}\text { pneumonia, Escherichia coli, } \\
\text { Mycobacterium luteus, } \\
\text { V. cholerae }\end{array}$ & [69] \\
\hline & $\begin{array}{c}\text { Allium cepa (bulb), Allium } \\
\text { sativum (bulb), Petroselinum } \\
\text { crispum (leaves) }\end{array}$ & 70 & Hexagonal wurtzite & $\begin{array}{l}\text { Photodegradation of methylene } \\
\text { blue }\end{array}$ & {$[48]$} \\
\hline & Phyllanthus niruri (leaves) & 25.61 & Quasispherical & Catalytic activity & {$[70]$} \\
\hline & $\begin{array}{l}\text { Parthenium hysterophorus } \\
\text { (leaves) }\end{array}$ & $27-84$ & Spherical and hexagonal & $\begin{array}{c}\text { Aspergillus flavus, Aspergillus } \\
\text { niger, Aspergillus fumigatus, } \\
\text { Fusarium culmorum, Fusarium } \\
\text { oxysporum }\end{array}$ & {$[71]$} \\
\hline & Solanum nigrum (leaves) & 29 & Quasispherical & $\begin{array}{c}\text { Staphylococcus aureus } \\
\text { Salmonella paratyphi, Vibrio } \\
\text { cholerae }\end{array}$ & {$[72]$} \\
\hline & Anisochilus carnosus (leaves) & $20-40$ & Hexagonal wurtzite & $\begin{array}{l}\text { S. paratyphi, V. cholerae, } \\
\text { S. aureus, and E. coli }\end{array}$ & {$[37]$} \\
\hline & Jacaranda mimosifolia (flower) & $2-4$ & Hexagonal wurtzite & $\begin{array}{c}\text { Escherichia coli, Enterococcus } \\
\text { faecium }\end{array}$ & {$[73]$} \\
\hline \multirow[t]{2}{*}{$\begin{array}{l}\text { Seaweed- } \\
\text { mediated } \\
\text { synthesis }\end{array}$} & $\begin{array}{c}\text { Caulerpa peltata, Hypnea } \\
\text { valencia, Sargassum } \\
\text { myriocystum }\end{array}$ & 36 & $\begin{array}{l}\text { Rectangle, triangle, } \\
\text { radial, and spherical }\end{array}$ & $\begin{array}{c}\text { Antibacterial activity against } \\
\text { Staphylococcus aureus, } \\
\text { Streptococcus mutans, Vibrio } \\
\text { cholerae, Neisseria gonorrhoeae, } \\
\text { Klebsiella pneumonia, and } \\
\text { antifungal activity against } \\
\text { Aspergillus niger and Candia sp. }\end{array}$ & {$[74]$} \\
\hline & Ulva lactuca & $10-50$ & $\begin{array}{l}\text { Hexagonal, rods, and } \\
\text { rectangles }\end{array}$ & $\begin{array}{c}\text { Photocatalytic, antibacterial, } \\
\text { antibiofilm, and larvicidal } \\
\text { activity }\end{array}$ & {$[75]$} \\
\hline \multirow{2}{*}{$\begin{array}{l}\text { Microbe- } \\
\text { mediated } \\
\text { synthesis }\end{array}$} & Aspergillus fumigatus & $60-80$ & Spherical & Antibacterial activity & {$[76]$} \\
\hline & Aeromonas hydrophila & 57 & Spherical and oval & Antimicrobial activity & {$[41]$} \\
\hline
\end{tabular}

thermal decomposition of zinc acetate maintaining the original $\mathrm{pH}$ of the reaction mixtures. Baskar et al. [90] produced $\mathrm{ZnO}$ NPs using Aspergillus terreus filtrate synthesized extracellularly which were spherical with a range of 54.8 to $82.6 \mathrm{~nm}$.

The nanoparticle's extracellular synthesis from the fungus is extremely beneficial due to economic viability, convenient downstream processing, and large-scale production [91]. Fungal strains are preferred over bacterial due to their enhanced metal bioaccumulation property and tolerance property [92]. From mycelia of Aspergillus fumigatus, the $\mathrm{ZnO}$ nanoparticles are synthesized [93]. By utilizing Candida albicans, the nanoparticles were synthesized with similar size ranging from 15 to $25 \mathrm{~nm}$ established through XRD, TEM, and SEM analysis [89].

\section{Characterization of ZnO NPs}

The synthesized nanoparticles are characterized by utilizing numerous techniques: FTIR (Fourier transform infrared spectroscopy), EDAX (energy dispersion analysis of X-ray), AFM (atomic force microscopy), XPS (X-ray photoelectron microscopy), ATR (attenuated total reflection), UV-DRS (UV-visible diffuse reflectance spectroscopy), XRD (X-ray diffractometer), TEM (transmission electron microscopy), TG-DTA (thermogravimetric-differential thermal analysis), DLS (dynamic light scattering), FE-SEM (field emission scanning electron microscopy), PL (photoluminescence analysis), Raman spectroscopy, and SEM (scanning electron microscopy) [94-96]. Plants are being examined extensively particularly that belong to Lamiaceae family such as Vitex 


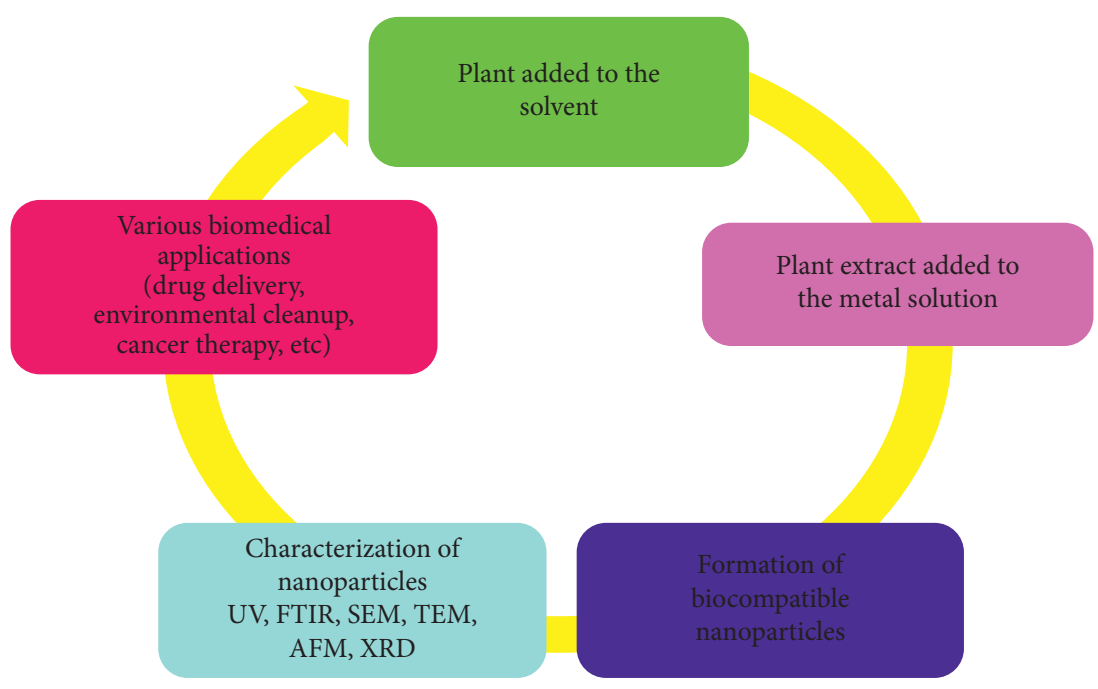

Figure 1: Plant-mediated biosynthesis of $\mathrm{ZnO}$ NPs.

negundo [97], Plectranthus amboinicus [98], and Anisochilus carnosus [37] which had the formation of NP with different shapes such as hexagonal, rod-shaped with agglomerates, quasispherical, and spherical, and further various sizes are also seen. From the outcome, it is clearly identified that the size of synthesized NPs is decreased on increasing the concentration of a plant extract $[70,77]$. From the results, the size range is being observed and compared using various techniques such as TEM, XRD, and FE-SEM which had a closer range of values [77, 98], whereas SEM and EDAX had a similar result diverse from XRD results. Through Debye-Scherrer equation, synthesis of NPs from both Vitex negundo flower and leaf had a similar size of $38.17 \mathrm{~nm}$, which was confirmed through XRD analysis [77]. For the synthesizing $\mathrm{ZnO}$ NPs, leaves of Azadirachta indica from Meliaceae family are generally being used $[99,100]$. A similar size range of NPs was identified in every experiment, which was confirmed through the analysis of TEM and XRD with nanobuds, hexagonal disc shape, and spherical shape. From the studies, it is revealed that the formation of NPs is through the involvement of amine, carboxylic acid, carbonate moieties, alcohol, alkane, and amide, which was further confirmed by FTIR studies. Aloe vera's leaf peel and fresh leaf extract belong to Liliaceae family [101, 102]. Agglomerate formation was seen in the NP synthesis, which was extracted from Moringa oleifera, Calotropis gigantea, Plectranthus amboinicus, Agathosma betulina, Nephelium lappaceum, and Pongamia pinnata. To affirm the synthesis of NPs, UV-Vis spectrophotometry is employed, and the crystal NPs are obtained through centrifugation of mixture and drying the pellet in a hot air oven [95].

\section{Biomedical Applications of ZnO NPs}

6.1. Drug Delivery. The benefits of using ZnO NPs for the drug delivery were derived from their two main basic properties. First of all, due to their smaller size, nanoparticles can penetrate through smaller capillaries and are absorbed by the cells, allowing an efficient accumulation of drugs at the target sites. Second, the use of biodegradable materials for the preparation of nanoparticles allows the prolonged discharge of drugs within the site targeted over a period of days or even weeks [103]. The role of synthesized ZnO NPs in drug release by using the drug metronidazole benzoate was studied [68] by observing its diffusion through egg membrane. Results revealed that the presence of $\mathrm{ZnO}$ NPs with the drug has much effect on the biological membrane.

6.2. Bioimaging of $\mathrm{ZnO}$ Particles. In preclinical research, fluorescence imaging is extensively utilized as it is convenient and inexpensive [104-107]. As $\mathrm{ZnO}$ nanomaterials have essential excitonic blue and near-UV emission, which has green luminescence associated with $\mathrm{O}_{2}$ vacancies $[108,109]$, and for cellular imaging, there are numerous reports existing in previous studies on the utilization of $\mathrm{ZnO}$ nanomaterials. For cancer cell imaging, transferrin-conjugated green fluorescent $\mathrm{ZnO}$ NPs were utilized with least cytotoxicity [110]. ZnO nanomaterial's optical properties could be altered by adulterating with suitable elements [111]. According to a research, $\mathrm{ZnO}$ NPs were adulterated with various cations such as $\mathrm{Co}$, $\mathrm{Cu}$, or $\mathrm{Ni}$, and in aqueous colloidal solutions, it was stabilized, which was employed in different cells for cellular imaging studies [112]. These tiny $\mathrm{ZnO}$ nanoparticles have a capability to penetrate it into the cell nucleus.

For biocompatibility and optical properties, heterostructural $\mathrm{ZnO} / \mathrm{Au}$ nanocomposites, where $\mathrm{Au}$ NCs develop either along the nanorod surfaces or at the tip of $\mathrm{ZnO}$ nanorods, are synthesized and investigated [113]. For imaging of cancer cells in vitro, antiepidermal growth factor receptor antibody-conjugated $\mathrm{ZnO}$ nanorods were utilized in the latest research [114]. For optical imaging, QDs are extensively deliberated nanoparticles because of their numerous appealing optical properties [115-117]. It was identified that $\mathrm{ZnO}$ QDs are placed in the cytoplasm while applying for in vitro cell imaging, exhibiting stable luminescence under UV light in the absence of essential cytotoxicity. Same QDs were analyzed in a previous research 
which was trialed through mice after injecting intravenous and intradermal injections [118].

Every imaging technique has their own benefits and drawbacks [119]. Through multiple imaging modalities, nanomaterials could be functionalized to be detectable, which produce synergistic advantages. Nanomaterials are more appropriate for multimodality imaging while associated with small molecules since larger surface area provides higher sites for functionalization and also helps to engineer them for multimodal detection. In one particular research, Gd-doped $\mathrm{ZnO}$ QDs (with sizes of less than $6 \mathrm{~nm}$ ) were emerged for both magnetic resonance imaging (MRI) and optical imaging [120]. Another study by Singh reported $\mathrm{Fe}_{3} \mathrm{O}_{4}-\mathrm{ZnO}$ core-shell magnetic QDs for potential cancer imaging and therapy.

There are better clinical relevance for single-photon emission computed tomography (SPECT) [122-126] and radionuclide-based imaging techniques, that is, PET [127132], which are extensively utilized in the clinic than in optical imaging. PET and SPECT techniques are not only highly sensitive and quantitative but also have no tissue penetration limitation [133-136].

\subsection{Drug Delivery with $\mathrm{ZnO}$ Nanomaterials. $\mathrm{ZnO}$ nano-} materials are versatile nanoplatforms not only in bioimaging but also in a drug delivery application because of their versatile surface chemistry, large surface area, and phototoxic effect, along with others. Researches in vitro have identified that $\mathrm{ZnO}$ nanoparticles could be highly toxic either for cancer cells [126] or for bacteria and leukemic $\mathrm{T}$ cells [137].

Intrinsic blue fluorescence of $\mathrm{ZnO}$ QDs was smeared with folate-conjugated chitosan through electrostatic interaction, and by doxorubicin, it can be loaded at $~ 75 \%$ efficiency (extensively utilized chemotherapy drug is DOX) [138]. It was recommended that through hydrogen bonding and/or through collaborations with the $\mathrm{ZnO} \mathrm{QD}$ surface, DOX was entrapped. But the aqueous stability of the $\mathrm{ZnO}$ QDs enriched the exterior chitosan layer because of the hydrophilicity and the charges. Conversely, at the normal physiological $\mathrm{pH}$ value of 7.4, DOX was released rapidly which requires to be improved for investigations in in vivo or in vitro researches.

In dendritic cell- (DC-) established cancer immunotherapy, one of the main complications is the improvement of delivery system which could provide the targeted antigens into DCs efficiently [139]. Due to extensive surface area, nanomaterials are challenging aspects for this application.

To deliver carcinoembryonic antigen into DCs, $\mathrm{Fe}_{3} \mathrm{O}_{4}$ $\mathrm{ZnO}$ core-shell nanoparticles were produced with an average diameter of $16 \mathrm{~nm}$ which have the capability to help as imaging contrast agents [140].

6.4. Gene Delivery with $\mathrm{ZnO}$ Nanomaterials. Over the last few years, gene therapy has involved substantial attention over cancer treatment [141]. Developing a safe gene vectors which could safeguard DNA from degradation as well as through high efficiency enabling cellular uptake of DNA is one of the foremost challenging aspects. For examining gene therapy application and gene delivery, extensive varieties of nanomaterials are utilized, which even comprise $\mathrm{ZnO}$ nanomaterial that had a positive outcome in numerous studies.

By a sequence of investigations, $\mathrm{ZnO}$ nanostructures, which are also like a three-dimensional tetrapod, were examined as gene vectors for delivering pEGFPN1 DNA (comprising the gene for green fluorescent protein) to A375 human melanoma cells [142, 143]. Through electrostatic interactions, the pDNA (plasmid DNA) was attached to $\mathrm{ZnO}$ nanostructures, and for gene delivery within the cells, the three needle-shaped legs preferred the internalization of the tips. It was observed that there was an absence for significant cytotoxicity which was reportedly attributed for the threedimensional geometry.

For an efficient gene delivery, surface coating of nanomaterial acts as a significant role. According to an investigation, $\mathrm{ZnO}$ QDs were layered using positively charged poly(2-(dimethylamino)ethyl methacrylate) (PDMAEMA) polymers which are utilized for condensing pDNA for gene delivery [144]. The polymer-coated $\mathrm{ZnO}$ QDs presented fluorescence emission at $570 \mathrm{~nm}$ with a considerable amount of less than $20 \%$ which is capable of condensing large pDNA just like luciferase reporter gene. It was stated that COS-7 cells can be transfected proficiently with pDNA transmitting $\mathrm{ZnO}$ QDs with lower cytotoxicity. The ZnO QDs had a significantly decreased cytotoxicity in association with the application of PDMAEMA as the gene vector. The decrease in cytotoxicity was due to the existence of negatively charged polymethacrylate in the QDs which stabilized the positive charges.

6.5. Biosensors based on $\mathrm{ZnO}$ Nanomaterials. Biosensors are extensively utilized in food industry, environmental monitoring, and healthcare and in chemical or biological analysis. Examples for biosensors are electrochemical, photometric, piezoelectric, and calorimetric among others when categorized based on the detection principles [145].

Nanomaterials, either as uncombined or as combination with biologically active substances, are attaining everincreasing awareness because of their capability to deliver a suitable platform for developing high-performance biosensors, which is due to their distinctive features [23]. For instance, the higher surface area of nanomaterials could be utilized for immobilizing numerous biomolecules such as antibodies, enzymes, and other proteins. Moreover, they could be permitted for a direct electron transfer among the electrodes and the active sites of the biomolecules.

$\mathrm{ZnO}$ nanomaterials also provide numerous desirable traits apart from semiconducting properties such as biosensing, strong adsorption capability, high isoelectric point, and high catalytic efficiency (IEP; 9.5) which are appropriate for adsorption of certain proteins such as antibodies and enzymes with less IEPs by electrostatic interaction [146]. Moreover, the favorable conditions of nanomaterials to be used in biosensors are lower toxicity, higher electron transfer capability, higher surface area, and better biocompatibility 
or stability [147]. The most widely stated $\mathrm{ZnO}$-based biosensors are recognized for numerous small-molecule analytes such as cholesterol, phenol, urea, glucose, $\mathrm{H}_{2} \mathrm{O}_{2}$, and many more other things. Additionally, there are numerous biosensors for sensing other molecules and certain physical or chemical properties like $\mathrm{pH}[148,149]$.

\section{Toxicity Studies of ZnO NPs}

Due to the increasing use of nanoparticles and their release in the environment, it is necessary to determine the toxicity of nanoparticles. Vicario-Pares et al. [150] conducted a toxicity study of three metal oxide nanoparticles, namely, $\mathrm{CuO}$ NPs (copper oxide nanoparticles), $\mathrm{ZnO} N \mathrm{NP}$, and $\mathrm{TiO}_{2}$ NPs against zebra fish embryo. ZnO NPs were found to be less toxic than the ionic form of zinc, which exerts the highest toxicity. Studies of Zhu et al. [151] showed that $\mathrm{ZnO}$ NP toxicity is dose dependent. Similarly, Jeyabharathi et al. [152] evaluated the toxicity study of green synthesized $\mathrm{ZnO}$ NPs towards zebra fish embryos. The author synthesized $\mathrm{ZnO}$ NPs from Amaranthus caudatus leaf extract. Further, $\mathrm{ZnO}$ NPs were found to exhibit a higher antibacterial activity against Staphylococcus epidermidis and Enterobacter aerogenes. Results of the toxicity study show that ZnO NPs at a concentration of $10 \mathrm{mg} / \mathrm{ml}$ did not show any significant effect on survival and malformation in the zebra fish embryo. In a 90-day toxicity study, $100 \mathrm{~nm} \mathrm{ZnO} \mathrm{NPs} \mathrm{with} \mathrm{different}$ surface charges (negatively charged, ZnOAE100 [-] and positively charged ZnOAE100 [+]) were administered to Sprague Dawley rats to determine the toxic level and to identify target organs. Significant toxic effects were observed in both sexes at a concentration greater than $125 \mathrm{mg} / \mathrm{kg}$. Also, there was an absence of adverse effect level at a concentration of about $31.25 \mathrm{mg} / \mathrm{kg}$ for both sexes [153].

\section{Conclusions}

Overall, from the study reviews, it is considered that green $\mathrm{ZnO} \mathrm{NP}$ synthesis is much safer and environmentally friendly than the physical and chemical methods. ZnO NPs are one of the most important and versatile materials, due to their diverse properties, functionalities, various benefits, and applications to humans. The green sources act as a stabilizing and reducing agent for the synthesis of nanoparticles of controlled size and shape. Holistically, the ZnO NP application to crops increases the growth and yield in agriculture. As demand for food is increasing day by day, the yield of a staple crop is low. Thus, it is necessary to commercialize metal oxide nanoparticles for sustainable agriculture. On the other hand, its biomedical applications in this sector are increased day by day in various processes including bioimaging, drug delivery, biosensors, and gene delivery. With respect to its toxicity properties, $\mathrm{ZnO}$ NPs can act as smart weapons against multiple drug-resistant microorganisms and as a talented substitute for antibiotics. It is anticipated that this review could further streamline the research on innovative methodological and clinical correlations in this area. In the meantime, solutions to health problems will be suggested by referring to this complex through scientific and research reports.

\section{Conflicts of Interest}

The authors declare no conflicts of interest.

\section{References}

[1] H. Mirzaei and M. Darroudi, "Zinc oxide nanoparticles: biological synthesis and biomedical applications," Ceramics International, vol. 43, no. 1, pp. 907-914, 2017.

[2] S. C. C. Arruda, A. L. D. Silva, R. M. Galazzi, R. A. Azevedo, and M. A. Z. Arruda, "Nanoparticles applied to plant science: a review," Talanta, vol. 131, pp. 693-705, 2015.

[3] H. Agarwal, S. V. Kumar, and S. Rajeshkumar, "A review on green synthesis of zinc oxide nanoparticles-an eco-friendly approach," Resource-Efficient Technologies, vol. 3, no. 4, pp. 406-413, 2017.

[4] H. A. Salam, R. Sivaraj, and R. Venckatesh, "Green synthesis and characterization of zinc oxide nanoparticles from Ocimum basilicum L. var. purpurascens Benth.-Lamiaceae leaf extract," Materials Letters, vol. 131, pp. 16-18, 2014.

[5] P. T. Anastas and J. C. Warner, Green Chemistry: Theory and Practice, Oxford University Press, Oxford, UK, 2000.

[6] W. Cai and X. Chen, "Nanoplatforms for targeted molecular imaging in living subjects," Small, vol. 3, no. 11, pp. 18401854, 2007.

[7] H. Hong, Y. Zhang, J. Sun, and W. Cai, "Molecular imaging and therapy of cancer with radiolabeled nanoparticles," Nano Today, vol. 4, no. 5, pp. 399-413, 2009.

[8] Y. Zhang, H. Hong, D. V. Myklejord, and W. Cai, "Molecular imaging with SERS-active nanoparticles," Small, vol. 7, no. 23, pp. 3261-3269, 2011.

[9] M. V. Yigit and Z. Medarova, "In vivo and ex vivo applications of gold nanoparticles for biomedical SERS imagingi," American Journal of Nuclear Medicine and Molecular Imaging, vol. 2, no. 2, pp. 232-241, 2012.

[10] J. E. Hutchison, "Greener nanoscience: a proactive approach to advancing applications and reducing implications of nanotechnology," ACS Nano, vol. 2, no. 3, pp. 395-402, 2008.

[11] W. Cai, A. R. Hsu, Z.-B. Li, and X. Chen, "Are quantum dots ready for in vivo imaging in human subjects?," Nanoscale Research Letters, vol. 2, no. 6, pp. 265-281, 2007.

[12] W. Cai and H. Hong, "In a "nutshell": intrinsically radiolabeled quantum dots," American Journal of Nuclear Medicine and Molecular Imaging, vol. 2, no. 2, pp. 136-140, 2012.

[13] L. R. Hirsch, A. M. Gobin, A. R. Lowery et al., "Metal nanoshells," Annals of Biomedical Engineering, vol. 34, no. 1, pp. 15-22, 2006.

[14] L. Lacerda, A. Bianco, M. Prato, and K. Kostarelos, "Carbon nanotubes as nanomedicines: From toxicology to pharmacology «," Advanced Drug Delivery Reviews, vol. 58, no. 14, pp. 1460-1470, 2006.

[15] H. Hong, T. Gao, and W. Cai, "Molecular imaging with single-walled carbon nanotubes," Nano Today, vol. 4, no. 3, pp. 252-261, 2009.

[16] Z. L. Wang, "Splendid one-dimensional nanostructures of zinc oxide: a new nanomaterial family for nanotechnology," ACS Nano, vol. 2, no. 10, pp. 1987-1992, 2008.

[17] P. Yang, R. Yan, and M. Fardy, "Semiconductor nanowire: what's next?," Nano Letters, vol. 10, no. 5, pp. 1529-1536, 2010. 
[18] M. H. Huang, Y. Wu, H. Feick, N. Tran, E. Weber, and P. Yang, "Catalytic growth of zinc oxide nanowires by vapor transport," Advanced Materials, vol. 13, no. 2, pp. 113-116, 2001.

[19] Z. Fan and J. G. Lu, "Zinc oxide nanostructures: synthesis and properties," Journal of Nanoscience and Nanotechnology, vol. 5, no. 10, pp. 1561-1573, 2005.

[20] C. S. Lao, M.-C. Park, Q. Kuang et al., "Giant enhancement in UV response of $\mathrm{ZnO}$ nanobelts by polymer surface-functionalization," Journal of the American Chemical Society, vol. 129, no. 40, pp. 12096-12097, 2007.

[21] X. Wang, J. Liu, J. Song, and Z. L. Wang, "Integrated nanogenerators in biofluid," Nano Letters, vol. 7, no. 8, pp. 2475-2479, 2007.

[22] Y. Yang, W. Guo, Y. Zhang, Y. Ding, X. Wang, and Z. L. Wang, "Piezotronic effect on the output voltage of $\mathrm{P} 3 \mathrm{HT} / \mathrm{ZnO}$ micro/nanowire heterojunction solar cells," Nano Letters, vol. 11, no. 11, pp. 4812-4817, 2011.

[23] R. Yakimova, " $\mathrm{ZnO}$ materials and surface tailoring for biosensing," Frontiers in Bioscience, vol. E4, no. 1, pp. 254278, 2012.

[24] J. Zhou, N. S. Xu, and Z. L. Wang, "Dissolving behavior and stability of $\mathrm{ZnO}$ wires in biofluids: a study on biodegradability and biocompatibility of $\mathrm{ZnO}$ nanostructures," Advanced Materials, vol. 18, no. 18, pp. 2432-2435, 2006.

[25] Y. Zhang, T. Nayak, H. Hong, and W. Cai, "Biomedical applications of zinc oxide nanomaterials," Current Molecular Medicine, vol. 13, no. 10, pp. 1633-1645, 2013.

[26] M. Pandurangan and D. H. Kim, "In vitro toxicity of zinc oxide nanoparticles: a review," Journal of Nanoparticle Research, vol. 17, no. 3, p. 158, 2015.

[27] V. N. Kalpana and V. D. Rajeswari, "Biosynthesis of metal and metal oxide nanoparticles for food packaging and preservation: a green expertise," Food Biosynthesis, pp. 293-316, 2017.

[28] A. Bose, Emerging Trends of Nanotechnology in Pharmacy, Pharmainfo, 2016, http://www.pharmainfo.net/book/ emerging-trends-nanotechnology-pharmacy-1introductionnanotechnology/classification.

[29] A. Alagarasi, Introduction to Nanomaterials, National Centre for Catalysis Research, Chennai, India, 2011, https://nccr. iitm.ac.in/2011.pdf.

[30] V. Thirumalai Arasu, D. Prabhu, and M. Soniya, "Stable silver nanoparticle synthesizing methods and its applications," Journal of Biosciences Research, vol. 1, pp. 259-270, 2010.

[31] G. Rajakumar, T. Gomathi, M. Thiruvengadam, V. D. Rajeswari, V. N. Kalpana, and I. M. Chung, "Evaluation of anti-cholinesterase, antibacterial and cytotoxic activities of green synthesized silver nanoparticles using from Millettia pinnata flower extract," Microbial Pathogenesis, vol. 103, pp. 123-128, 2017.

[32] P. Raveendran, J. Fu, and S. L. Wallen, "Completely "green" synthesis and stabilization of metal nanoparticles," Journal of the American Chemical Society, vol. 125, no. 46, pp. 13940-13941, 2003.

[33] P. Dhandapani, S. Maruthamuthu, and G. Rajagopal, "Biomediated synthesis of $\mathrm{TiO}_{2}$ nanoparticles and its photocatalytic effect on aquatic biofilm," Journal of Photochemistry and Photobiology B: Biology, vol. 110, pp. 43-49, 2012.

[34] K. Prasad and A. K. Jha, "ZnO nanoparticles: synthesis and adsorption study," Natural Science, vol. 1, no. 2, pp. 129-135, 2009.
[35] S. Gunalan, R. Sivaraj, and V. Rajendran, "Green synthesized $\mathrm{ZnO}$ nanoparticles against bacterial and fungal pathogens," Progress in Natural Science: Materials International, vol. 22, no. 6, pp. 693-700, 2012.

[36] P. Vanathi, P. Rajiv, S. Narendhran, S. Rajeshwari, P. K. S. M. Rahman, and R. Venckatesh, "Biosynthesis and characterization of phyto mediated zinc oxide nanoparticles: a green chemistry approach," Materials Letters, vol. 134, pp. 13-15, 2014.

[37] M. Anbuvannan, M. Ramesh, G. Viruthagiri, N. Shanmugam, and N. Kannadasan, "Anisochilus carnosus leaf extract mediated synthesis of zinc oxide nanoparticles for antibacterial and photocatalytic activities," Materials Science in Semiconductor Processing, vol. 39, pp. 621-628, 2015a.

[38] M. Sundrarajan, S. Ambika, and K. Bharathi, "Plant-extract mediated synthesis of $\mathrm{ZnO}$ nanoparticles using Pongamia pinnata and their activity against pathogenic bacteria," Advanced Powder Technology, vol. 26, no. 5, pp. 1294-1299, 2015.

[39] B. N. Patil and T. C. Taranath, "Limonia acidissima L. leaf mediated synthesis of zinc oxide nanoparticles: a potent tool against Mycobacterium tuberculosis," International Journal of Mycobacteriology, vol. 5, no. 2, pp. 197-204, 2016.

[40] P. Jamdagni, P. Khatri, and J. S. Rana, "Green synthesis of zinc oxide nanoparticles using flower extract of Nyctanthes arbor-tristis and their antifungal activity," Journal of King Saud University-Science, vol. 30, no. 2, pp. 168-175, 2018.

[41] C. Jayaseelan, A. Abdul Rahuman, and A. Vishnu Kirthi, "Novel microbial route to synthesize $\mathrm{ZnO}$ nanoparticles using Aeromonas hydrophila and their activity against pathogenic bacteria and fungi," Spectrochimica Acta Part A: Molecular and Biomolecular Spectroscopy, vol. 90, pp. 78-84, 2012.

[42] M. R. Parra and F. Z. Haque, "Aqueous chemical route synthesis and the effect of calcination temperature on the structural and optical properties of $\mathrm{ZnO}$ nanoparticles," Journal of Materials Research and Technology, vol. 3, no. 4, pp. 363-369, 2014.

[43] G. Sangeetha, S. Rajeshwari, and R. Venckatesh, "Green synthesis of zinc oxide nanoparticles by aloe barbadensis miller leaf extract: Structure and optical properties," Materials Research Bulletin, vol. 46, no. 12, pp. 2560-2566, 2011.

[44] Z. Sheikhloo, M. Salouti, and F. Katiraee, "Biological synthesis of gold nanoparticles by fungus Epicoccum nigrum," Journal of Cluster Science, vol. 22, no. 4, pp. 661-665, 2011.

[45] E. D. Sherly, J. Judith Vijaya, N. Clament Sagaya Selvam, and L. John Kennedy, "Microwave assisted combustion synthesis of coupled $\mathrm{ZnO}-\mathrm{ZrO}_{2}$ nanoparticles and their role in the photocatalytic degradation of 2,4-dichlorophenol," Ceramics International, vol. 40, no. 4, pp. 5681-5691, 2014.

[46] K. Elumalai and S. Velmurugan, "Green synthesis, characterization and antimicrobial activities of zinc oxide nanoparticles from the leaf extract of Azadirachta indica (L.)," Applied Surface Science, vol. 345, pp. 329-336, 2015.

[47] V. Patel, D. Berthold, P. Puranik, and M. Gantar, "Screening of cyanobacteria and microalgae for their ability to synthesize silver nanoparticles with antibacterial activity," Biotechnology Reports, vol. 5, pp. 112-119, 2015.

[48] M. Stan, A. Popa, D. Toloman, A. Dehelean, I. Lung, and G. Katona, "Enhanced photocatalytic degradation properties of zinc oxide nanoparticles synthesized by using plant extracts," Materials Science in Semiconductor Processing, vol. 39, pp. 23-29, 2015. 
[49] A. Umar, M. M. Rahman, M. Vaseem, and Y. B. Hahn, "Ultra-sensitive cholesterol biosensor based on lowtemperature grown $\mathrm{ZnO}$ nanoparticles," Electrochemistry Communications, vol. 11, no. 1, pp. 118-121, 2009.

[50] J. Liu, C. Guo, C. M. Li et al., "Carbon-decorated $\mathrm{ZnO}$ nanowire array: a novel platform for direct electrochemistry of enzymes and biosensing applications," Electrochemistry Communications, vol. 11, no. 1, pp. 202-205, 2009.

[51] K. Bahrami, M. M. Khodaei, and A. Nejati, "One-pot synthesis of 1, 2, 4, 5-tetrasubstituted and 2, 4, 5-trisubstituted imidazoles by zinc oxide as efficient and reusable catalyst," Monatshefte für Chemie-Chemical Monthly, vol. 142, no. 2, pp. 159-162, 2011.

[52] R. Tayebee, F. Cheravi, M. Mirzaee, and M. M. Amini, "Commercial zinc oxide ( $\mathrm{Zn} 2+)$ as an efficient and environmentally benign catalyst for homogeneous benzoylation of hydroxyl functional groups," Chinese Journal of Chemistry, vol. 28, no. 7, pp. 1247-1252, 2010.

[53] C. R. Gorla, N. W. Emanetoglu, S. Liang et al., "Structural, optical, and surface acoustic wave properties of epitaxial $\mathrm{ZnO}$ films grown on (0112) sapphire by metalorganic chemical vapor deposition," Journal of Applied Physics, vol. 85, no. 5, pp. 2595-2602, 1999.

[54] M. S. Akhtar, S. Ameen, S. A. Ansari, and O. Yang, "Synthesis and characterization of $\mathrm{ZnO}$ nanorods and balls nanomaterials for dye sensitized solar cells," Journal of Nanoengineering and Nanomanufacturing, vol. 1, no. 1, pp. 71-76, 2011.

[55] N. P. Sasidharan, P. Chandran, and S. S. Khan, "Interaction of colloidal zinc oxide nanoparticles with bovine serum albumin and its adsorption isotherms and kinetics," Colloids and Surfaces B: Biointerfaces, vol. 102, pp. 195-201, 2013.

[56] L. Zhang, Y. Ding, M. Povey, and D. York, "ZnO nanofluidsa potential antibacterial agent," Progress in Natural Science, vol. 18, no. 8, pp. 939-944, 2008.

[57] J. Xie, H. Deng, Z. Q. Xu, Y. Li, and J. Huang, "Growth of ZnO photonic crystals by self-assembly," Journal of Crystal Growth, vol. 292, no. 2, pp. 227-229, 2006.

[58] C. Liewhiran and S. Phanichphant, "Improvement of flamemade $\mathrm{ZnO}$ nanoparticulate thick film morphology for ethanol sensing," Sensors, vol. 7, no. 5, pp. 650-675, 2007.

[59] B. Ajitha, Y. A. K. Reddy, P. S. Reddy, H. J. Jeon, and C. W. Ahn, "Role of capping agents in controlling silver nanoparticles size, antibacterial activity and potential application as optical hydrogen peroxide sensor," RSC Advances, vol. 6, no. 42, pp. 36171-36179, 2016.

[60] P. J. P. Espitia, N. D. F. F. Soares, J. S. Dos Reis Coimbra, N. J. De Andrade, R. S. Cruz, and E. A. A. Medeiros, "Zinc oxide nanoparticles: synthesis, antimicrobial activity and food packaging applications," Food and Bioprocess Technology, vol. 5, no. 5, pp. 1447-1464, 2012.

[61] W. H. Elmer and J. C. White, "The use of metallic oxide nanoparticles to enhance growth of tomatoes and eggplants in disease infested soil or soilless medium," Environmental Science: Nano, vol. 3, no. 5, pp. 1072-1079, 2016.

[62] N. A. N. Mohamad, N. A. Arham, J. Jai, and A. Hadi, "Plant extract as reducing agent in synthesis of metallic nanoparticles: a review," Advanced Materials Research, vol. 832, pp. 350-355, 2014.

[63] V. V. Makarov, A. J. Love, O. V. Sinitsyna et al., "“Green” nanotechnologies: synthesis of metal nanoparticles using plants," Acta Naturae, vol. 6, no. 1, p. 20, 2014.

[64] A. G. Ingale and A. N. Chaudhari, "Biogenic synthesis of nanoparticles and potential applications: an eco-friendly approach," Journal of Nanomedicine and Nanotechnology, vol. 4, no. 165, pp. 1-7, 2013.

[65] S. M. Roopan, V. D. Rajeswari, V. N. Kalpana, and G. Elango, "Biotechnology and pharmacological evaluation of Indian vegetable crop Lagenaria siceraria: an overview," Applied Microbiology and Biotechnology, vol. 100, no. 3, pp. 11531162, 2015.

[66] M. S. Geetha, H. Nagabhushana, and H. N. Shivananjaiah, "Green mediated synthesis and characterization of $\mathrm{ZnO}$ nanoparticles using Euphorbia Jatropha latex as reducing agent," Journal of Science: Advanced Materials and Devices, vol. 1, no. 3, pp. 301-310, 2016.

[67] M. Murali, C. Mahendra, Nagabhushan et al., "Antibacterial and antioxidant properties of biosynthesized zinc oxide nanoparticles from Ceropegia candelabrum L.-an endemic species," Spectrochimica Acta Part A: Molecular and Biomolecular Spectroscopy, vol. 179, no. 179, pp. 104-109, 2017.

[68] J. Vaishnav, V. Subha, S. Kirubanandan, M. Arulmozhi, and S. Renganathan, "Green synthesis of zinc oxide nanoparticles by Celosia argentea and its characterization," Journal of Optoelectronic and Biomedical Materials, vol. 9, pp. 59-71, 2017.

[69] G. Sathishkumar, C. Rajkuberan, K. Manikandan, S. Prabukumar, J. Daniel John, and S. Sivaramakrishnan, "Facile biosynthesis of antimicrobial zinc oxide $(\mathrm{ZnO})$ nanoflakes using leaf extract of Couroupita guianensis Aubl," Materials Letters, vol. 188, pp. 383-386, 2017.

[70] M. Anbuvannan, M. Ramesh, G. Viruthagiri, N. Shanmugam, and N. Kannadasan, "Synthesis, characterization and photocatalytic activity of $\mathrm{ZnO}$ nanoparticles prepared by biological method," Spectrochimica Acta Part A: Molecular and Biomolecular Spectroscopy, vol. 143, pp. 304-308, 2015.

[71] P. Rajiv, S. Rajeshwari, and R. Venckatesh, "Bio-fabrication of zinc oxide nanoparticles using leaf extract of Parthenium hysterophorus L. and its size-dependent antifungal activity against plant fungal pathogens," Spectrochimica Acta Part A: Molecular and Biomolecular Spectroscopy, vol. 112, pp. 384-387, 2013.

[72] M. Ramesh, M. Anbuvannan, and G. Viruthagiri, "Green synthesis of $\mathrm{ZnO}$ nanoparticles using Solanum nigrum leaf extract and their antibacterial activity," Spectrochimica Acta Part A: Molecular and Biomolecular Spectroscopy, vol. 136, pp. 864-870, 2015.

[73] D. Sharma, M. I. Sabela, S. Kanchi et al., "Biosynthesis of $\mathrm{ZnO}$ nanoparticles using Jacaranda mimosifolia flowers extract: Synergistic antibacterial activity and molecular simulated facet specific adsorption studies," Journal of Photochemistry and Photobiology B: Biology, vol. 162, pp. 199-207, 2016.

[74] S. Nagarajan and K. A. Kuppusamy, "Extracellular synthesis of zinc oxide nanoparticle using seaweeds of gulf of Mannar, India," Journal of Nanobiotechnology, vol. 11, no. 1, p. 39, 2013.

[75] R. Ishwarya, B. Vaseeharan, S. Kalyani et al., "Facile green synthesis of zinc oxide nanoparticles using Ulva lactuca seaweed extract and evaluation of their photocatalytic, antibiofilm and insecticidal activity," Journal of Photochemistry and Photobiology B: Biology, vol. 178, pp. 249-258, 2018.

[76] A. Rajan, E. Cherian, and G. Baskar, "Biosynthesis of zinc oxide nanoparticles using Aspergillus fumigatus JCF and its antibacterial activity," International Journal of Modern Science and Technology, vol. 1, pp. 52-57, 2016. 
[77] S. Ambika and M. Sundrarajan, "Antibacterial behaviour of Vitex negundo extract assisted $\mathrm{ZnO}$ nanoparticles against pathogenic bacteria," Journal of Photochemistry and Photobiology B: Biology, vol. 146, pp. 52-57, 2015.

[78] R. Dobrucka and J. Długaszewska, "Biosynthesis and antibacterial activity of $\mathrm{ZnO}$ nanoparticles using Trifolium pratense flower extract," Saudi Journal of Biological Sciences, vol. 23, no. 4, pp. 517-523, 2016.

[79] V. N. Kalpana, C. Payel, and V. Devi Rajeswari, "Lagenaria siceraria aided green synthesis of $\mathrm{ZnO}$ NPs: anti-dandruff, Anti-microbial and Anti-arthritic activity," Research Journal of Chemistry and Environment, vol. 21, no. 11, pp. 14-19, 2017.

[80] A. C. Dhanemozhi, V. Rajeswari, and S. Sathyajothi, "Green synthesis of zinc oxide nanoparticle using green tea leaf extract for supercapacitor application," Mater Today: Proceedings, vol. 4, no. 2, pp. 660-667, 2017.

[81] J. Santhoshkumar, S. V. Kumar, and S. Rajeshkumar, "Synthesis of zinc oxide nanoparticles using plant leaf extract against urinary tract infection pathogen," Resource-Efficient Technologies, vol. 3, no. 4, pp. 459-465, 2017.

[82] O. J. Nava, P. A. Luque, C. M. Gomez-Gutiérrez et al., "Influence of Camellia sinensis extract on zinc oxide nanoparticle green synthesis," Journal of Molecular Structure, vol. 1134, pp. 121-125, 2017.

[83] B. Siripireddy and B. K. Mandal, "Facile green synthesis of zinc oxide nanoparticles by Eucalyptus globulus and their photocatalytic and antioxidant activity," Advanced Powder Technology, vol. 28, no. 3, pp. 785-797, 2017.

[84] F. T. Thema, E. Manikandan, M. S. Dhlamini, and M. Maaza, "Green synthesis of $\mathrm{ZnO}$ nanoparticles via Agathosma betulina natural extract," Materials Letters, vol. 161, pp. 124-127, 2015.

[85] M. Z. Hussein, W. H. W. N. Azmin, M. Mustafa, and A. H. Yahaya, "Bacillus cereus as a biotemplating agent for the synthesis of zinc oxide with raspberry-and plate-like structures," Journal of Inorganic Biochemistry, vol. 103, no. 8, pp. 1145-1150, 2009.

[86] D. Kundu, C. Hazra, A. Chatterjee, A. Chaudhari, and S. Mishra, "Extracellular biosynthesis of zinc oxide nanoparticles using Rhodococcus pyridinivorans NT2: multifunctional textile finishing, biosafety evaluation and in vitro drug delivery in colon carcinoma," Journal of Photochemistry and Photobiology B: Biology, vol. 140, pp. 194-204, 2014.

[87] P. Dhandapani, A. S. Siddarth, S. Kamalasekaran, S. Maruthamuthu, and G. Rajagopal, "Bio-approach: ureolytic bacteria mediated synthesis of $\mathrm{ZnO}$ nanocrystals on cotton fabric and evaluation of their antibacterial properties," Carbohydrate Polymers, vol. 103, pp. 448-455, 2014.

[88] E. Selvarajan and V. Mohanasrinivasan, "Biosynthesis and characterization of $\mathrm{ZnO}$ nanoparticles using Lactobacillus plantarum VITES07," Materials Letters, vol. 112, pp. 180$182,2013$.

[89] A. Shamsuzzaman, A. Mashrai, H. Khanam, and R. N. Aljawfi, "Biological synthesis of $\mathrm{ZnO}$ nanoparticles using C. albicans and studying their catalytic performance in the synthesis of steroidal pyrazolines," Arabian Journal of Chemistry, vol. 10, pp. S1530-S1536, 2017.

[90] G. Baskar, J. Chandhuru, K. S. Fahad, and A. S. Praveen, "Mycological synthesis, characterization and antifungal activity of zinc oxide nanoparticles," Asian Journal of Pharmacy and Technology, vol. 3, no. 4, pp. 142-146, 2013.

[91] S. Azizi, M. B. Ahmad, F. Namvar, and R. Mohamad, "Green biosynthesis and characterization of zinc oxide nanoparticles using brown marine macroalga Sargassum muticum aqueous extract," Materials Letters, vol. 116, pp. 275-277, 2014.

[92] R. Pati, R. K. Mehta, and S. Mohanty, “Topical application of zinc oxide nanoparticles reduces bacterial skin infection in mice and exhibits antibacterial activity by inducing oxidative stress response and cell membrane disintegration in macrophages," Nanomedicine: Nanotechnology, Biology and Medicine, vol. 10, no. 6, pp. 1195-1208, 2014.

[93] K. Pavani, N. Kumar, and B. Sangameswaran, "Synthesis of lead nanoparticles by Aspergillus species," Polish Journal of Microbiology, vol. 61, no. 1, pp. 61-63, 2012.

[94] Y. A. Arfat, S. Benjakul, T. Prodpran, P. Sumpavapol, and P. Songtipya, "Properties and antimicrobial activity of fish protein isolate/fish skin gelatin film containing basil leaf essential oil and zinc oxide nanoparticles," Food Hydrocolloids, vol. 41, pp. 265-273, 2014.

[95] A. Yasmin, K. Ramesh, and S. Rajeshkumar, "Optimization and stabilization of gold nanoparticles by using herbal plant extract with microwave heating," Nano Convergence, vol. 1, no. 1, p. 12, 2014.

[96] S. Rajeshkumar, C. Malarkodi, M. Vanaja, and G. Annadurai, "Anticancer and enhanced antimicrobial activity of biosynthesizd silver nanoparticles against clinical pathogens," Journal of Molecular Structure, vol. 1116, pp. 165-173, 2016.

[97] L.-E. Shi, Z.-H. Li, W. Zheng, Y.-F. Zhao, Y.-F. Jin, and Z.-X. Tang, "Synthesis, antibacterial activity, antibacterial mechanism and food applications of $\mathrm{ZnO}$ nanoparticles: a review," Food Additives and Contaminants: Part A, vol. 31, no. 2, pp. 173-186, 2014.

[98] L. Fu and Z. Fu, "Plectranthus amboinicus leaf extractassisted biosynthesis of $\mathrm{ZnO}$ nanoparticles and their photocatalytic activity," Ceramics International, vol. 41, no. 2, pp. 2492-2496, 2015.

[99] T. Bhuyan, K. Mishra, M. Khanuja, R. Prasad, and A. Varma, "Biosynthesis of zinc oxide nanoparticles from Azadirachta indica for antibacterial and photocatalytic applications," Materials Science in Semiconductor Processing, vol. 32, pp. 55-61, 2015.

[100] H. R. Madan, S. C. Sharma, Udayabhanu et al., "Facile green fabrication of nanostructure $\mathrm{ZnO}$ plates, bullets, flower, prismatic tip, closed pine cone: their antibacterial, antioxidant, photoluminescent and photocatalytic properties," Spectrochimica Acta Part A: Molecular and Biomolecular Spectroscopy, vol. 152, pp. 404-416, 2016.

[101] Y. Qian, J. Yao, M. Russel, K. Chen, and X. Wang, "Characterization of green synthesized nano-formulation ( $\mathrm{ZnO}-A$. vera) and their antibacterial activity against pathogens," Environmental Toxicology and Pharmacology, vol. 39, no. 2, pp. 736-746, 2015.

[102] K. Ali, S. Dwivedi, and A. Azam, "Aloe vera extract functionalized zinc oxide nanoparticles as nanoantibiotics against multi-drug resistant clinical bacterial isolates," Journal of Colloid and Interface Science, vol. 472, pp. 145-156, 2016.

[103] N. C. Shinde, N. J. Keskar, and P. D. Argade, "Nanoparticles: advances in drug delivery systems," Research Journal of Pharmaceutical, Biological and Chemical Sciences, vol. 3, no. 1, pp. 922-929, 2012.

[104] W. Cai and H. Hong, "Peptoid and positron emission tomography: an appealing combination," American Journal of Nuclear Medicine and Molecular Imaging, vol. 1, no. 1, pp. 76-79, 2011.

[105] X. Huang, S. Lee, and X. Chen, "Design of "smart" probes for optical imaging of apoptosis," American Journal of Nuclear Medicine and Molecular Imaging, vol. 1, no. 1, pp. 3-17, 2011. 
[106] R. E. Wang, Y. Niu, H. Wu, M. N. Amin, and J. Cai, "Development of NGR peptide-based agents for tumor imaging," American Journal of Nuclear Medicine and Molecular Imaging, vol. 1, no. 1, pp. 36-46, 2011.

[107] D. L. Thorek, R. Robertson, W. A. Bacchus et al., "Cerenkov imaging-a new modality for molecular imaging," American Journal of Nuclear Medicine and Molecular Imaging, vol. 2, no. 2, pp. 163-173, 2012.

[108] K. Vanheusden, W. L. Warren, C. H. Seager, D. R. Tallant, J. A. Voigt, and B. E. Gnade, "Mechanisms behind green photoluminescence in $\mathrm{ZnO}$ phosphor powders," Journal of Applied Physics, vol. 79, no. 10, pp. 7983-7990, 1996.

[109] Y. W. Heo, D. P. Norton, and S. J. Pearton, "Origin of green luminescence in $\mathrm{ZnO}$ thin film grown by molecular-beam epitaxy," Journal of Applied Physics, vol. 98, no. 7, article 073502, 2005.

[110] S. Sudhagar, S. Sathya, K. Pandian, and B. S. Lakshmi, "Targeting and sensing cancer cells with $\mathrm{ZnO}$ nanoprobes in vitro," Biotechnology Letters, vol. 33, no. 9, pp. 1891-1896, 2011.

[111] F. Xue, J. Liang, and H. Han, "Synthesis and spectroscopic characterization of water-soluble $\mathrm{Mn}$-doped $\mathrm{ZnOxS1-x}$ quantum dots," Spectrochimica Acta Part A: Molecular and Biomolecular Spectroscopy, vol. 83, no. 1, pp. 348-352, 2011.

[112] Y. L. Wu, S. Fu, A. I. Y. Tok et al., "A dual-colored biomarker made of doped ZnO nanocrystals," Nanotechnology, vol. 19, no. 34, article 345605, 2008.

[113] W. Q. Zhang, Y. Lu, T.-K. Zhang et al., "Controlled synthesis and biocompatibility of water-soluble $\mathrm{ZnO}$ nanorods/ $\mathrm{Au}$ nanocomposites with tunable UV and visible emission intensity," Journal of Physical Chemistry C, vol. 112, no. 50, pp. 19872-19877, 2008.

[114] S. C. Yang, Y.-C. Shen, T.-C. Lu, T.-L. Yang, and J.-J. Huang, "Tumor detection strategy using $\mathrm{ZnO}$ light-emitting nanoprobes," Nanotechnology, vol. 23, no. 5, article 055202, 2012.

[115] X. Michalet, F. F. Pinaud1, L. A. Bentolila et al., "Quantum dots for live cells, in vivo imaging, and diagnostics," Science, vol. 307, no. 5709, pp. 538-544, 2005.

[116] I. L. Medintz, H. Tetsuo Uyeda, E. R. Goldman, and H. Mattoussi, "Quantum dot bioconjugates for imaging, labelling and sensing," Nature Materials, vol. 4, no. 6, pp. 435-446, 2006.

[117] W. Cai, Y. Zhang, and T. J. Kamp, "Imaging of induced pluripotent stem cells: from cellular reprogramming to transplantation," American Journal of Nuclear Medicine and Molecular Imaging, vol. 1, no. 1, pp. 18-28, 2011.

[118] Z. Y. Pan, J. Liang, Z.-Z. Zheng, H.-H. Wang, and H.-M. Xiong, "The application of $\mathrm{ZnO}$ luminescent nanoparticles in labeling mice," Contrast Media and Molecular Imaging, vol. 6, no. 4, pp. 328-330, 2011.

[119] T. F. Massoud and S. Gambhir, "Molecular imaging in living subjects: seeing fundamental biological processes in a new light," Genes and Development, vol. 17, no. 5, pp. 545-580, 2003.

[120] Y. Liu, K. Ai, Q. Yuan, and L. Lu, "Fluorescence-enhanced gadolinium-doped zinc oxide quantum dots for magnetic resonance and fluorescence imaging," Biomaterials, vol. 32, no. 4, pp. 1185-1192, 2011.

[121] S. Singh, "Multifunctional magnetic quantum dots for cancer theranostics," Journal of Biomedical Nanotechnology, vol. 7, no. 1, pp. 95-97, 2011.

[122] K. Murugan, M. Roni, C. Panneerselvam et al., "Sargassum wightii-synthesized $\mathrm{ZnO}$ nanoparticles reduce the fitness and reproduction of the malaria vector Anopheles stephensi and cotton bollworm Helicoverpa armigera," Physiological and Molecular Plant Pathology, vol. 101, 2017.

[123] P. R. Gandhi, C. Jayaseelan, R. R. Mary, D. Mathivanan, and S. R. Suseem, "Acaricidal, pediculicidal and larvicidal activity of synthesized $\mathrm{ZnO}$ nanoparticles using Momordica charantia leaf extract against blood feeding parasites," Experimental Parasitology, vol. 181, pp. 47-56, 2017.

[124] S. Rajeshwari, K. S. M. Rahman, P. Rajiv, and R. Venckatesh, "Biogenic zinc oxide nanoparticles synthesis using Tabernaemontana divaricate leaf extract and its anticancer activity against MCF-7 breast cancer cell lines," in Proceedings of the International Conference on Agriculture, Biology and Environmental Science, pp. 83-85, Rome Italy, September 2014.

[125] M. J. Akhtar, M. Ahamed, S. Kumar, M. M. Khan, J. Ahmad, and S. A. Alrokayan, "Zinc oxide nanoparticles selectively induce apoptosis in human cancer cells through reactive oxygen species," International Journal of Nanomedicine, vol. 7, p. 845, 2012.

[126] C. Hanley, J. Layne, A. Punnoose et al., "Preferential killing of cancer cells and activated human $\mathrm{T}$ cells using $\mathrm{ZnO}$ nanoparticles," Nanotechnology, vol. 19, no. 29, pp. 95-103, 2008.

[127] S. S. Gambhir, "Molecular imaging of cancer with positron emission tomography," Nature Reviews Cancer, vol. 2, no. 9, pp. 683-693, 2002.

[128] J. F. Eary, D. S. Hawkins, E. T. Rodler, and E. U. Conrad, "18F-FDG PET in sarcoma treatment response imaging," American Journal of Nuclear Medicine and Molecular Imaging, vol. 1, no. 1, pp. 47-53, 2011.

[129] A. Iagaru, "18F-FDG PET/CT: timing for evaluation of response to therapy remains a clinical challenge," American Journal of Nuclear Medicine and Molecular Imaging, vol. 1, no. 1, pp. 63-64, 2011.

[130] W. Vach, P. F. Høilund-Carlsen, B. M. Fischer, O. Gerke, and W. Weber, "How to study optimal timing of PET/CT for monitoring of cancer treatment," American Journal of $\mathrm{Nu}$ clear Medicine and Molecular Imaging, vol. 1, no. 1, pp. 54-62, 2011.

[131] M. M. Alauddin, "Positron emission tomography (PET) imaging with 18F-based radiotracers," American Journal of Nuclear Medicine and Molecular Imaging, vol. 2, no. 1, pp. 55-76, 2012.

[132] I. Grassi, C. Nanni, V. Allegri et al., "The clinical use of PET with 11C-acetate," American Journal of Nuclear Medicine and Molecular Imaging, vol. 2, no. 1, pp. 33-47, 2012.

[133] T. Buckle, N. S. van Berg, J. Kuil et al., "Non-invasive longitudinal imaging of tumor progression using an (111) indium labeled CXCR4 peptide antagonist," American Journal of Nuclear Medicine and Molecular Imaging, vol. 2, no. 1, pp. 99-109, 2012.

[134] M. D. Saint-Huberte, L. Brepoels, E. Devos et al., "Molecular imaging of therapy response with 18F-FLT and 18F-FDG following cyclophosphamide and mTOR inhibition," American Journal of Nuclear Medicine and Molecular Imaging, vol. 2, no. 1, pp. 110-121, 2012.

[135] M. Sun, D. Hoffman, G. Sundaresan, L. Yang, N. Lamichhane, and J. Zweit, "Synthesis and characterization of intrinsically radiolabeled quantum dots for bimodal detection," American Journal of Nuclear Medicine and Molecular Imaging, vol. 2, no. 2, pp. 122-135, 2012.

[136] Y. Zhang, T. R. Nayak, H. Hong, and W. Cai, "Graphene: a versatile nanoplatform for biomedical applications," Nanoscale, vol. 4, no. 13, p. 3833, 2012.

[137] H. Wang, D. Wingett, M. H. Engelhard et al., "Fluorescent dye encapsulated $\mathrm{ZnO}$ particles with cell-specific toxicity for 
potential use in biomedical applications," Journal of Materials Science: Materials in Medicine, vol. 20, no. 1, pp. 11-22, 2009.

[138] Q. Yuan, S. Hein, and R. D. K. Misra, "New generation of chitosan-encapsulated $\mathrm{ZnO}$ quantum dots loaded with drug: synthesis, characterization and in vitro drug delivery response," Acta Biomaterialia, vol. 6, no. 7, pp. 2732-2739, 2010.

[139] C. G. Figdor, I. J. M. de Vries, W. Joost Lesterhuis, and C. J. M. Melief, "Dendritic cell immunotherapy: mapping the way," Nature Medicine, vol. 10, no. 5, pp. 475-480, 2004.

[140] N. H. Cho, T.-C. Cheong, J. H. Min et al., "A multifunctional core-shell nanoparticle for dendritic cell-based cancer immunotherapy," Nature Nanotechnology, vol. 6, no. 10, pp. 675-682, 2011.

[141] F. McCormick, "Cancer gene therapy: fringe or cutting edge?," Nature Reviews Cancer, vol. 1, no. 2, pp. 130-141, 2001.

[142] L. Nie, L. Gao, P. Feng et al., "Three-dimensional functionalized tetrapod-like $\mathrm{ZnO}$ nanostructures for plasmid DNA Delivery," Small, vol. 2, no. 5, pp. 621-625, 2006.

[143] L. Nie, L. Gao, X. Yan, and T. Wang, "Functionalized tetrapod-like $\mathrm{ZnO}$ nanostructures for plasmid DNA purification, polymerase chain reaction and delivery," Nanotechnology, vol. 18, no. 1, article 015101, 2007.

[144] P. Zhang and W. Liu, "ZnO QD@PMAA-co-PDMAEMA nonviral vector for plasmid DNA delivery and bioimaging," Biomaterials, vol. 31, no. 11, pp. 3087-3094, 2010.

[145] Z. Zhao, W. Lei, X. Zhang et al., "ZnO-based amperometric enzyme biosensors," Sensors, vol. 10, no. 2, pp. 1216-1231, 2010.

[146] J. X. Wang, X. W. Sun, A. Wei et al., "Zinc oxide nanocomb biosensor for glucose detection," Applied Physics Letters, vol. 88, no. 23, article 233106, 2006.

[147] S. A. Kumar and S. Chen, "Nanostructured zinc oxide particles in chemically modified electrodes for biosensor applications," Analytical Letters, vol. 41, no. 2, pp. 141-158, 2008.

[148] M. Willander and S. M. Al-Hilli, "ZnO nanorods as an intracellular sensor for $\mathrm{pH}$ measurements," Micro and Nano Technologies in Bioanalysis, vol. 102, pp. 187-200, 2009.

[149] V. Pachauri, A. Vlandas, K. Kern, and K. Balasubramanian, "Site-specific self-assembled liquid-gated $\mathrm{ZnO}$ nanowire transistors for sensing applications," Small, vol. 6, no. 4, pp. 589-594, 2010.

[150] U. Vicario-Pares, L. Castanaga, J. M. Lacave et al., "Comparative toxicity of metal oxide nanoparticles $(\mathrm{CuO}, \mathrm{ZnO}$ and $\mathrm{TiO} 2)$ to developing zebrafish embryos," Journal of Nanoparticle Research, vol. 16, no. 8, p. 2550, 2014.

[151] X. Zhu, L. Zhu, Z. Duan, R. Qi, Y. Li, and Y. Lang, "Comparative toxicity of several metal oxide nanoparticle aqueous suspensions to zebra fish (Danio rerio) early developmental stage," Journal of Environmental Science and Health, Part A, vol. 43, no. 3, pp. 278-284, 2008.

[152] S. Jeyabharathi, K. Kalishwaralal, K. Sundar, and A. Muthukumaran, "Synthesis of zinc oxide nanoparticles (ZnONPs) by aqueous extract of Amaranthus caudatus and evaluation of their toxicity and antimicrobial activity," Materials Letters, vol. 209, pp. 295-298, 2017.

[153] Y. R. Kim, J. I. Park, E. J. Lee et al., "Toxicity of $100 \mathrm{~nm}$ zinc oxide nanoparticles: a report of 90-day repeated oral administration in Sprague Dawley rats," International Journal of Nanomedicine, vol. 9, pp. 109-126, 2014. 

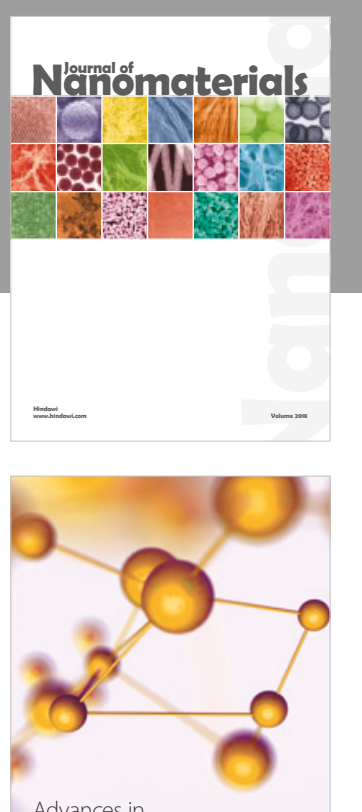

Physical Chemistry
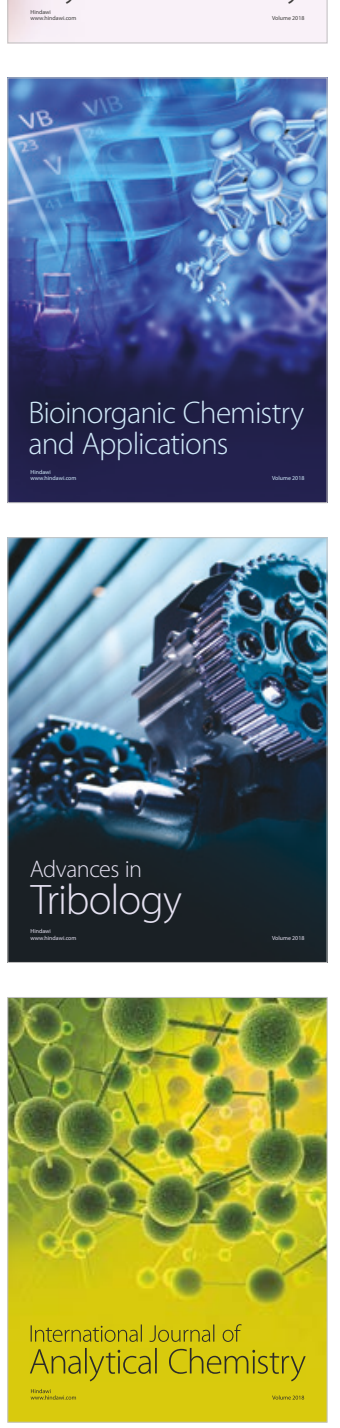

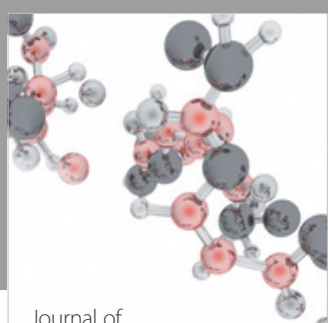

Analytical Methods

in Chemistry

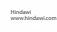

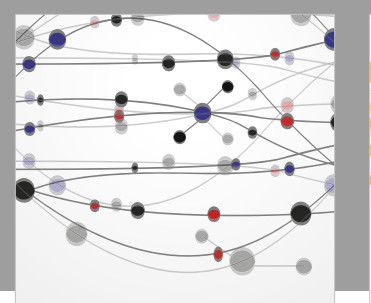

The Scientific World Journal

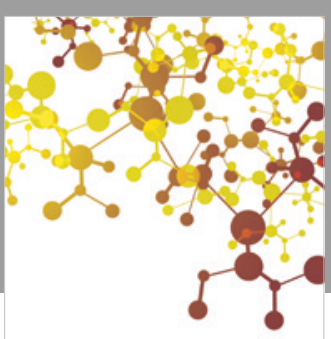

Journal of

Applied Chemistry
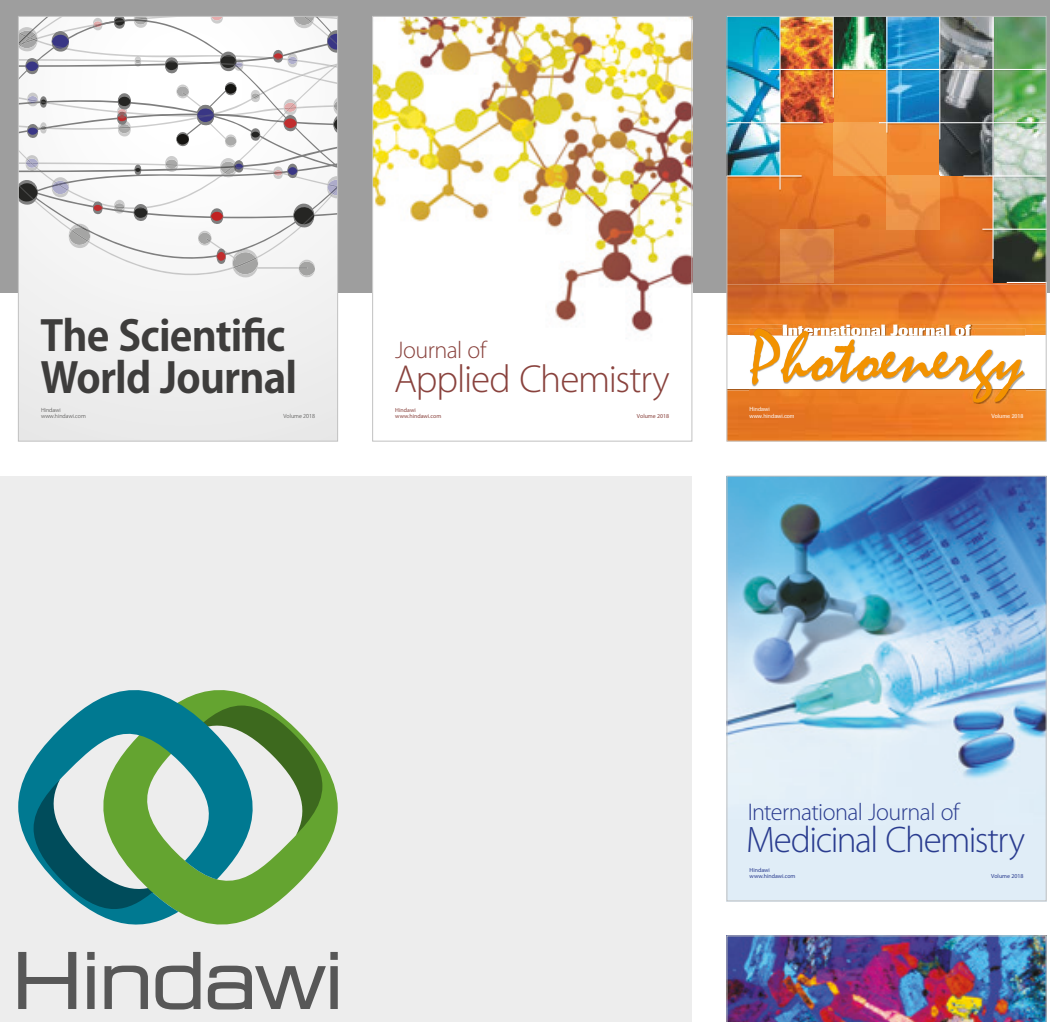

Submit your manuscripts at

www.hindawi.com
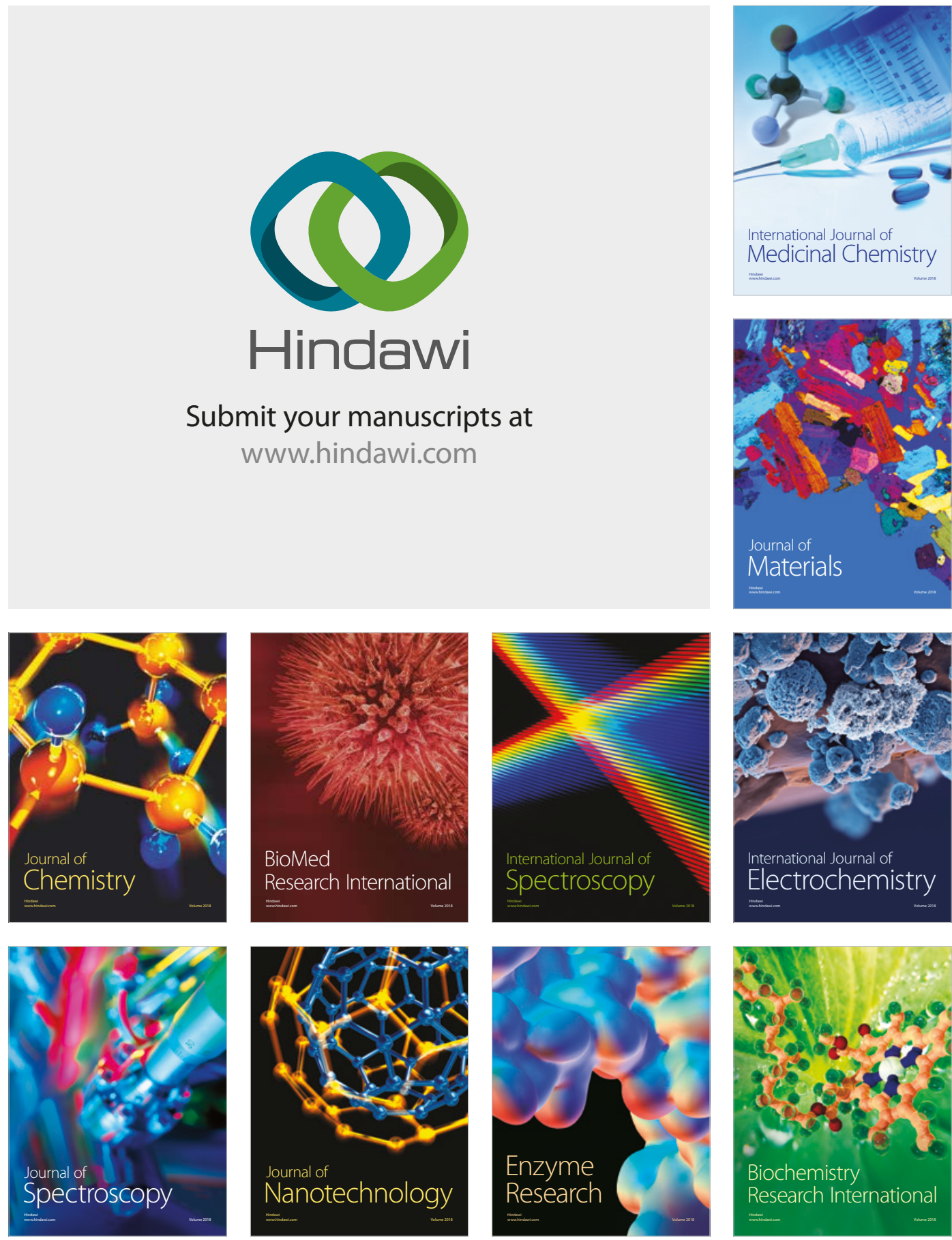
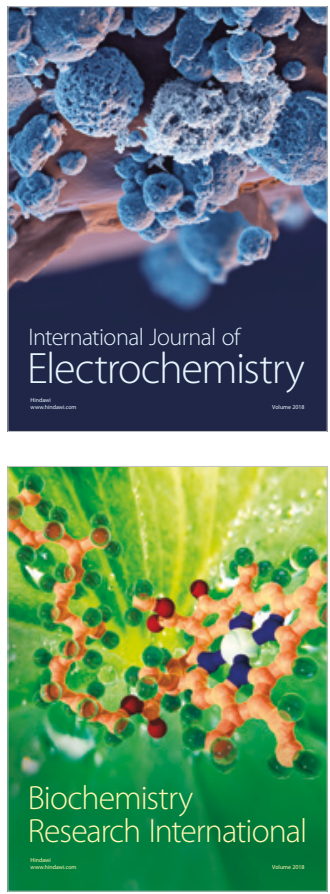